Article

\title{
Evidence for Wide Dispersal in a Stem Galliform Clade from a New Small-Sized Middle Eocene Pangalliform (Aves: Paraortygidae) from the Uinta Basin of Utah (USA)
}

\author{
Thomas A. Stidham ${ }^{1,2,3, *}$, K.E. Beth Townsend ${ }^{4}(-)$ and Patricia A. Holroyd ${ }^{5}$ \\ 1 Key Laboratory of Vertebrate Evolution and Human Origins of the Chinese Academy of Sciences, Institute of \\ Vertebrate Paleontology and Paleoanthropology, Chinese Academy of Sciences, Beijing 100044, China \\ 2 CAS-Center for Excellence in Life and Paleoenvironment, Beijing 100044, China \\ 3 University of Chinese Academy of Sciences, Beijing 10049, China \\ 4 Department of Anatomy, College of Graduate Studies, Midwestern University, 19555 N. 59th Avenue, \\ Glendale, AZ 85308, USA; btowns@midwestern.edu \\ 5 Museum of Paleontology, University of California, Berkeley, CA 94720, USA; pholroyd@berkeley.edu \\ * Correspondence: presbyornis@gmail.com
}

Received: 16 January 2020; Accepted: 19 February 2020; Published: 28 February 2020

\begin{abstract}
A new bird coracoid from the Uinta Formation in the Uinta Basin in Utah (USA) records the presence of the only known pangalliform from the middle Eocene of North America, occurring in a >15 million year gap in their history. This fossil represents a new taxon, informally termed the Uintan paraortygid, which is also currently the best-supported record of the extinct Paraortygidae in North America (and among the oldest records of the group in the world). The specimen exhibits a derived enlarged procoracoid prominence with a small procoracoid process, and concave elliptical scapular cotyle that are shared with the middle Eocene paraortygids, Xorazmortyx and Scopelortyx; however, the Uintan paraortygid also has a possibly autapomorphic (pneumatic) fossa adjacent to the scapular cotyle. The similarity in body size and morphology among these widely distributed early paraortygids suggests phylogenetic affinity among them. Given their occurrence in the United States, Uzbekistan, and Namibia during the middle Eocene, these birds likely were good fliers with an increased ability to disperse; and probably had a flexible biology or diet allowing them to occupy a diversity of habitats from coasts and forests to semi-arid savannah-like habitats. The problematic early records of Odontophoridae need to be reexamined as potential members of Paraortygidae and associates of these small-bodied taxa.
\end{abstract}

Keywords: coracoid; dispersal; Eocene; Galliformes; Paraortygidae; Uinta Formation; Utah

\section{Introduction}

Crown group Galliformes are a very familiar clade, with members such as megapodes, chachalacas, guineafowl, quail, and pheasants (including the domestic chicken) that are distributed on all continents, except Antarctica. The stem lineage leading to that diverse crown group (including several extinct groups within the total group Pangalliformes [1,2]) is documented by a wide variety of Eocene, Oligocene, and early Miocene fossils, and extinct taxa from Africa, South America, North America, Asia, and Europe (e.g., [3-10]). A recent reanalysis of Sylviornis and related fossils suggests that at least one lineage of pangalliformes outside of Galliformes survived into the late Holocene of New Caledonia and Fiji [11]. Aside from that Holocene material, the youngest records of stem galliforms are otherwise from the early Miocene (e.g., [2,7]). 
Despite the very wide geographic distribution of Paleogene stem galliforms (Asia, Africa, South America, North America, and Europe), the fossil record of stem galliforms is sparse in North America, and uncommon in the middle Eocene record around the world (Figure 1). Potential records of stem galliforms have been described from the Cretaceous of the USA: a small galloanserine quadrate from the late Maastrichtian Lance Formation in eastern Wyoming [12], Austinornis from the Campanian of Texas [1], and others [13]. The oldest recognized records of stem galliform birds in North America are the specimens of Gallinuloides wyomingensis (Gallinuloididae) from the early Eocene of Wyoming [5,14]. The extinct taxon Amitabha urbsinterditensis from the early middle Eocene (Bridgerian North American Land Mammal Age, NALMA) of Wyoming was described originally as a crown group member of Galliformes, but more recent work demonstrates that it is not a galliform relative, being instead a gruiform related to Rallidae [14]. Weigel [15] described Nanortyx inexpectus as a small species of New World quail (Odontophoridae) from the late Eocene ( $35 \mathrm{Ma}$ ) Calf Creek fauna of the Cypress Hills Formation of Saskatchewan, Canada, based on a partial tarsometatarsus and coracoid. That material has not been reassessed in detail (including the two additional coracoid fragments mentioned, but not described or illustrated by Weigel [15]). Nanortyx is likely a stem galliform, but not a member of Paraortygidae, based on the reported presence of a circular and cup-like scapular cotyle [16], which contrasts with the flattened scapular cotyle among crown galliforms and the elliptical cotyle in paraortygids (see below). While the late Eocene (Chadronian NALMA) and early Oligocene (Orellan NALMA) fossils from South Dakota and Nebraska named Procrax brevipes, Archaealectrornis sibleyi, and Palaeonossax senectus were published originally [17-19] as Galliformes, more recent data from Mayr [2,20] support not only their position outside of the crown group, but also their likely synonymy with one another. However, see Mayr and Weidig [5] for a hypothesis about a crown position for Procrax. Those fossils likely represent one or more non-crown group species that are approximately the size or slightly larger than the extant $\sim 500$ gram Chaco Chachalaca (Ortalis canicollis) $[20,21]$ and are much larger than Nanortyx [15]. If Mayr's more recent hypothesis about a non-crown phylogenetic position is correct, then it is possible that only three named species of Paleogene stem galliforms are known from North America (i.e., the early Eocene Gallinuloides wyomingensis, the late Eocene Nanortyx inexpectus, and the late Eocene-Oligocene Palaeonossax senectus, and its potential junior synonyms). A fossil originally published as the oldest odontophorid from the early Oligocene (Orellan NALMA) of Colorado [18] may represent another non-crown member of the galliform clade, but that partial tarsometatarsus needs to be reexamined. Given the published fossil record, there is a gap in the pangalliform fossil record in North America, more than 15 million years long (between specimens of Gallinuloides in the early Eocene and the holotypes of Nanortyx and Procrax, in the late Eocene; Figure 1).

Increasing the geographic examination of Paleogene pangalliforms, we see that this middle Eocene gap is global in its scope, though smaller than the North American gap ( $>5-10$ million years vs. $>15$ million years). This temporal dearth of specimens occurs between the youngest specimens of Gallinuloididae (Paraortygoides) from the early middle Eocene of Europe, and the oldest records of Quercymegapodiidae and Paraortygidae in the late Eocene of Europe [2,6,22]. The African record has a similar pattern with stem galliforms of unknown family clade affiliation, known from the late early or early middle Eocene of Tunisia (Chambiortyx cristata [8]) and early middle Eocene (early Lutetian, $\sim 47-49 \mathrm{Ma}$ ) of Namibia (Namaortyx sperrgebietenesis [23]). The Asian stem galliform record currently is restricted to the early Eocene [4,9] and one other younger specimen [10]. Potentially narrowing this global gap is Scopelortyx klinghardtensis assigned to the Paraortygidae from the late middle Eocene (Bartonian; 38-41.3 Ma) of Namibia [16], and the paraortygid Xorazmortyx turkestanensis [10] from the latest Lutetian or Bartonian of Uzbekistan. Thus, the size of the global middle Eocene gap is dependent on the age of the specimens of Scopelortyx and Xorazmortyx. Another published specimen hypothesized to be a pangalliform at the edges of this gap is Telecrex grangeri from the Irdin Manha Formation of Inner Mongolia, China. Telecrex was first published as an early rallid, but Olson [24] reassessed the fossil femur as the oldest known guineafowl (Numididae). Its phylogenetic position among pangalliforms has been questioned [6]. It appears that the late Eocene age estimate for the Irdin Manha Formation, 
repeated by many avian paleontological authors (e.g., $[9,10,20,24])$, has been revised to early middle Eocene ( $\sim 48-49 \mathrm{Ma})$ [25]. That age suggests the oldest known crown galliform (if Telecrex is a member of Numididae) is middle Eocene (Figure 1).

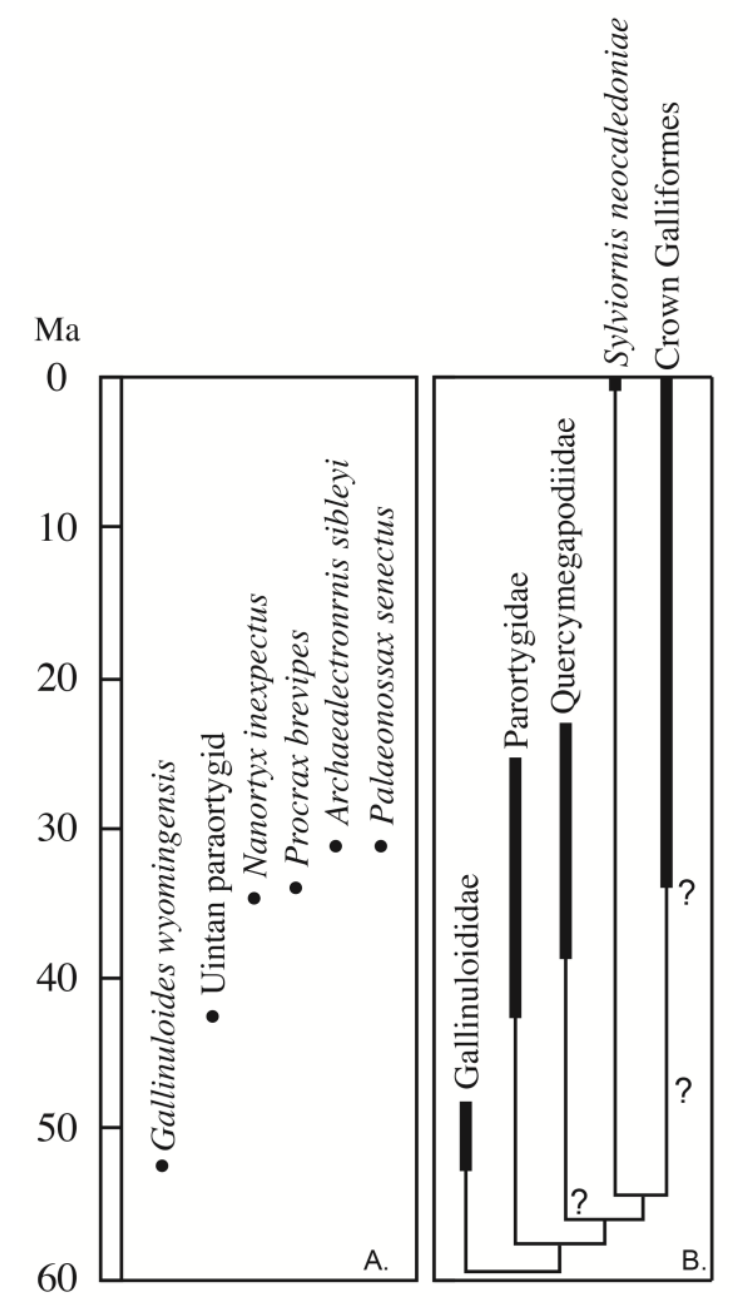

Figure 1. Phylogeny and temporal distribution of pangalliforms. (A) Temporal distribution of non-crown group pangalliforms in North America; (B) phylogeny and temporal distribution of Cenozoic pangalliforms with a focus on non-crown lineages [2,11]. Question marks indicate fossils possibly belonging to the lineage (see text for details).

This gap in our knowledge of the evolution of early pangalliforms is interesting because Mayr [2] has hypothesized that the shift to a large crop (and gastroliths in a gizzard) associated with a greater dietary component of seeds, and coarse plant matter likely occurred after the origin of Gallinuloididae in the early Eocene and before its arguable presence among later Eocene lineages (Quercymegapodiidae). Thus, the middle Eocene may have been a time of an increase in dietary breadth and a shift in pangalliform ecology. However, if the taxonomic allocation of the early Eocene ( $\sim 55 \mathrm{Ma})$ pangalliform from Mongolia to the Quercymegapodiidae is correct [9], then those features of the digestive track may have originated even earlier (i.e., Paleocene).

Expanding this meager fossil record in the middle Eocene is the discovery of a new coracoid fragment from an extinct paraortygid pangalliform from the middle Eocene Uinta Formation (Uintan NALMA, Lutetian), Uinta Basin of Utah (Figure 2). This fossil documents a new Paleogene species of small-bodied pangalliform that derives from a temporal gap in their North American (and global) history between the early Eocene Gallinuloides wyomingensis and late Eocene Nanortyx inexpectus. This 
new fossil possesses apparently unique morphological features among pangalliforms and derives from a bird comparable in size to the smallest extant galliforms.

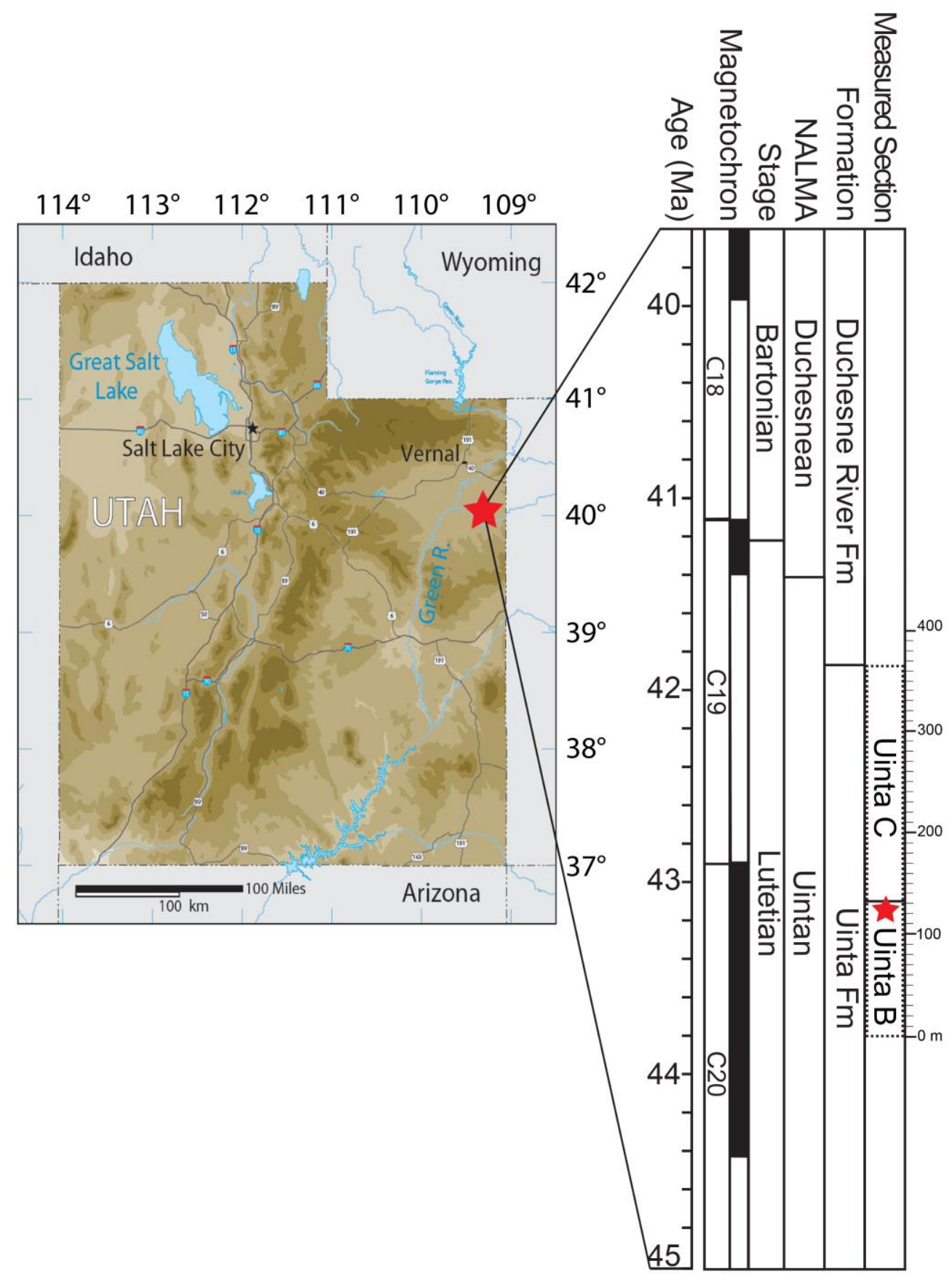

Figure 2. Geographic and stratigraphic position and correlation of the fossil locality (UMNH.VP.LOC 2734) of the Uintan paraortygid. The dotted lines represent the position of the measured stratigraphic section from Townsend et al. [26] relative to the Global Magnetic Polarity Time Scale based on correlation with the magnetostratigraphic section of Townsend et al. [27] and Prothero [28]. The red star indicates the position of UMNH.VP.LOC 2734 at $123 \mathrm{~m}$ within the measured section and on the map.

The Uinta Formation is exposed south of the Uinta Mountains in the Uinta Basin, an east-west trending synclinal basin in northeastern Utah [28]. The formation is approximately $1298 \mathrm{~m}$ thick and has a discontinuous outcrop that is traceable for approximately $145 \mathrm{~km}$ from the edge of the Utah-Colorado state line to the western edge of the Uinta Basin [29-35]. The Uinta Formation was deposited under 
fluvial conditions resulting from numerous streams and rivers feeding into the receding lake (Lake Uinta) that helped to form the underlying Green River Formation [36].

The Uinta Formation has been divided formally into the lower Wagonhound and upper Myton Members, yet most workers refer to the formation using a modified tripartite division of Osborn's [35] stratigraphic nomenclature, from lowest to highest: Uinta A; Uinta B; and Uinta C [25,32,37,38]. The lowest unit, Uinta A, intertongues with the Parachute Creek Member of the Green River Formation and is composed of medium to massive resistant fine-grained sandstones that are yellowish-brown and yellowish-gray, and about $226 \mathrm{~m}$ in thickness [32,39]. Uinta B sediments are dominated by non-resistant slopes composed of light-gray, light green-gray, light-brown, light-purple mudstones, and claystones [26,32]. The muds and clays are interbedded by green-gray, yellow, and brown fine-grained sandstone beds, as well as gilsonite veins in the lower intervals of this unit [26,32,40]. In the eastern part of the basin, Uinta B is capped by the massive gray and brown Amynodon sandstone that spans $1.6 \mathrm{~km}$ in length, and that sandstone was the original boundary between the Uinta B and Uinta $C$ horizons $[26,35,41]$. Uinta $C$ beds are light green, light gray, and light brown mudstones and claystones in the lower intervals, and the upper part is composed of mainly deep red-orange, red, dark brown, grayish-purple, and yellow muds and claystones with small green fine-grained sandstone beds interspersed throughout [26,32].

The Uinta Formation yields the type fauna for the Uintan NALMA, and recent fossil collecting efforts along with stratigraphic studies have made it possible to define biochronologic units and associated stratotype sections for this NALMA as Ui1, Ui2, and Ui3 [41]. The greatest faunal diversity is found in the Ui2 biochron, or early Uintan, which corresponds to the Uinta B sediments [42]. The locality where the pangalliform fossil was discovered is UMNH.VP.LOC.2734 (field locality number WU-117), and is at a 123 meter level of the stratigraphic section of Townsend et al. [26] considered to be Uinta B sediments (Figure 2) by those authors and Uinta C sediments by Sprinkel [32]. The locality is near the biochronological transition from Ui2 to Ui3, but clearly within the Ui2 biochron [42]. The typical Ui2 fauna includes multiple primate species, small bunodont artiodactyls, marsupials, leporids, micro-rodents (Microparamys, small sciuravids, cylindrodontids, and Protoptychus), larger ischyromyid rodents, pantolestids, agriochoerid and protoceratid artiodactyls, and larger ungulates such as Eobasileus, Achaenodon, Uintatherium, and brontotheriids. Non-mammalian vertebrates include a diverse array of turtles (carettochelyids, testudinids, baenids, and testudinoids), crocodiles, lizards, and fish. The incredible diversity of taxa typical of Ui2 is what is generally recovered in any given field season at UMNH.VP.LOC.2734 (WU-117).

Only two fossil birds are otherwise described from the Uinta Basin, both from the slightly younger Uinta $C$ beds. The original identification of Eonessa anaticula Wetmore [43] from the Myton Pocket in the Myton Member of the Uinta Formation was as an anseriform. Later work by Olson and Feuduccia [44] indicates that it is not anseriform, but possibly a member of the Gruiformes. Eutreptornis uintae was described originally as a cariamiform bathornithid, but its relationship to other taxa placed with bathornithids is unclear [45,46]. Townsend et al. [26] noted the presence of bird fossils at localities WU-170 and WU-117 (where the pangalliform specimen also was collected), but those specimens have yet to be studied.

\section{Materials}

Repository and institutional abbreviation. Museum of Vertebrate Zoology (MVZ), University of California, Berkeley, CA, USA. UMNH, Natural History Museum of Utah, UT, Salt Lake City, USA. Osteological terminology follows Baumel and Witmer [47] with English equivalents of many terms. The term procoracoid prominence is used below to designate the broad process extending medially from caudal (sternal) to the scapular cotyle, encompassing the scapular cotyle and procoracoid process (at its apex) near its center, and ending cranial (omal) to the scapular cotyle within the $\mathrm{m}$. supracoracoideus fossa (see Figure 3). 
A

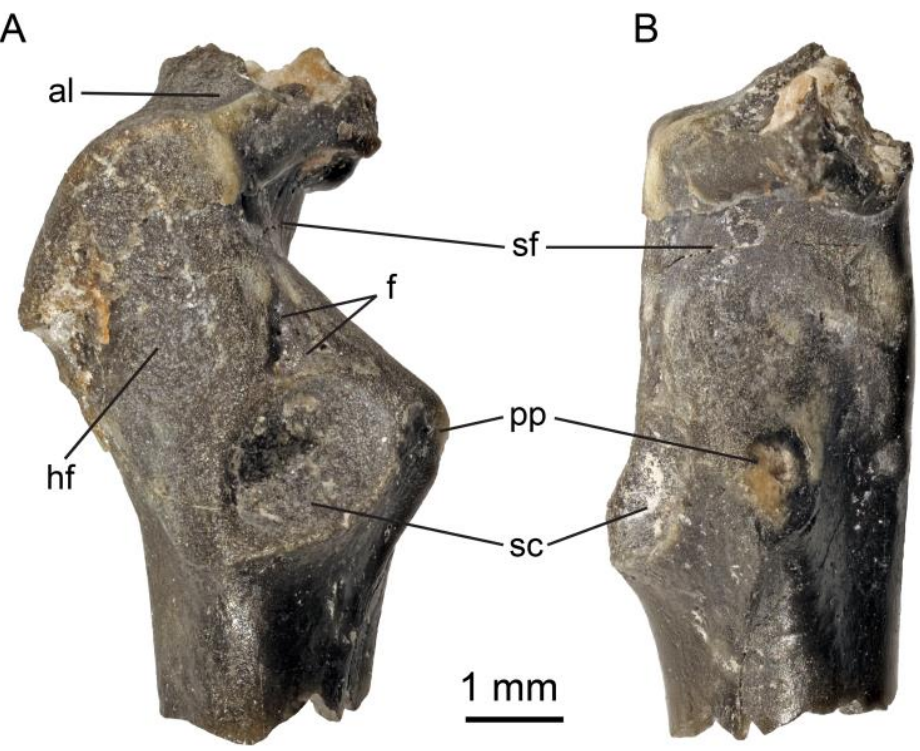

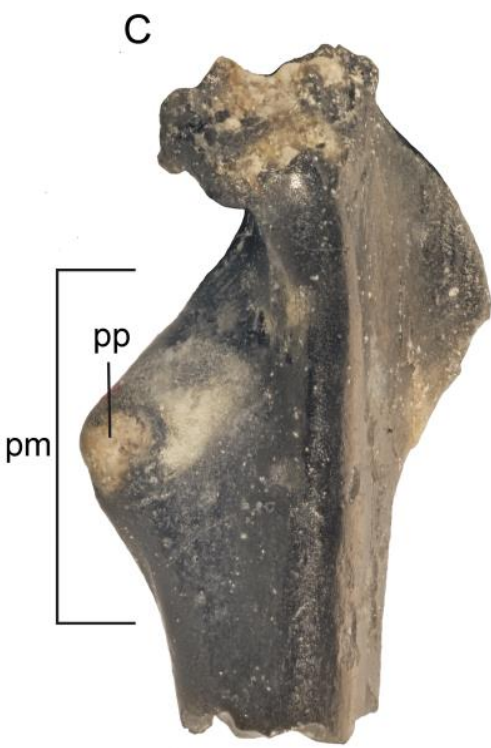

Figure 3. The coracoid of the Uintan paraortygid (UMNH.VP.30891) from the Eocene Uinta Formation. Coracoid in (A) dorsal; (B) medial; and (C) ventral views. Abbreviations: al—scar for the acrocoracohumeralis ligament; $\mathrm{f}$-fossa; hf-humeral articular facet; $\mathrm{pm}$-procoracoid prominence; $\mathrm{pp}$ - procoracoid process; sc—scapular cotyle; sf-m. supracoracoideus fossa.

\section{Systematic Paleontology}

Aves Linneaus, 1758 [48]

Pangalliformes Clarke, 2004 [1]

Paraortygidae Mourer-Chauviré, 1992 [6]

Unnamed species

Figure 3

Specimen

UMNH.VP.30891 is an omal end of a left coracoid collected by PAH from locality UMNH.VP.LOC.2734 (field number 18-019, Washington University locality WU-117) in the middle Eocene Uinta Formation of Utah, USA (Figures 2 and 3).

\section{Diagnostic Features}

The fossil shares with Paraortygidae a short procoracoid process and an elliptical outline of the scapular cotyle with a long axis oblique to the omal-sternal axis. The large procoracoid prominence with an elongate slope into the $\mathrm{m}$. supracoracoideus fossa is shared among the paraortygids the Uintan paraortygid, Xorazmortyx turkestanensis, and Scopelortyx klinghardtensis (Figure 3) [10,16], but the prominence extends medial to the medial edge of the acrocoracoid only in the Uintan paraortygid and Xorazmortyx. Those three taxa also share a short, obliquely oriented acrocoracoid crest [10]. The caudolateral margin of the humeral articular facet is nearly straight in the Uintan paraortygid, but concave in Scopelortyx and the most concave in Xorazmortyx. The Uintan paraortygid also differs from Scopelortyx and Xorazmortyx in having an acrocoracoid that overhangs the $\mathrm{m}$. supracoracoideus fossa, a craniocaudally shorter $\mathrm{m}$. supracoracoideus fossa, and the apex of the acrocoracoid (medial view) being in its ventral half. The medial margin of the coracoid shaft in the Uintan paraortygid does not bifurcate cranially as in Xorazmortyx, but the area where a pit would be present in Xorazmortyx is not preserved in the Uintan paraortygid specimen. The Uintan paraortygid has a straight dorsal margin to the humeral articular facet as in Xorazmortyx, but not Scopelortyx [10].

\section{Occurrence}


The fossil was found at locality UMNH.VP.LOC.2734, which is at the $123 \mathrm{~m}$ level above the base of section $C$ in the Uinta Formation, and that locality has produced other bird material along with primate fossils [26]. UMNH.VP.LOC.2734 contains the highest stratigraphic records of the mammals Epihippus gracilis, Mesomeryx grangeri, Ourayia uintensis, Pareumys milleri, and Protoptychus hatcheri [26]. The mammalian fauna is consistent with a biostratigraphic position within the Uintan B (near its top; Figure 2) or early Uintan Ui2 NALMA, and is likely 43-44 Ma in age [26]. The precise locality coordinates are not presented here, in compliance with the United States Paleontological Resources Preservation Act (PRPA) (PL 111-11), but are available to qualified researchers from the repository upon request.

\section{Description}

The coracoid fragment UMNH.VP.30891 is $7.0 \mathrm{~mm}$ long craniocaudally (omal-sternal). The humeral articular surface is approximately $5 \mathrm{~mm}$ long craniocaudally, and has a maximum mediolateral width of $2.8 \mathrm{~mm}$. The scapular cotyle is deeply concave and ovoid in outline. The long axis of that ovoid is oblique (approximately 45 degrees) to the mediolateral (and omal-sternal) axis of the bone with its apices located craniomedial and caudolateral. Near the medial apex of the cotyle is the greatly reduced but present procoracoid process that is missing its tip. The procoracoid prominence (with the procoracoid process at its apex) is the mediolaterally widest part of the specimen. The cranial part of the prominence slopes into the craniocaudally short $\mathrm{m}$. supracoracoideus fossa, resulting in a relatively craniocaudally short concave portion (dorsal view) of the fossa (in its cranial half). There is no evidence of any pneumatic foramina in the $\mathrm{m}$. supracoracoideus fossa, and the most-cranial (omal) part of the fossa is relatively flat. On the dorsal surface immediately cranial to the scapular cotyle is a small shallow fossa (that does not appear to be the result of wear or breakage) that is subtriangular in outline, with small (possibly pneumatic) foramina near the corners of the triangle (Figure 3). The humeral articular surface extends caudally to the caudolateral side of the cotyle, is concave over its surface, and widens cranially making its outline asymmetric. The dorsal surface of the coracoid shaft just caudal to the scapular cotyle is distinctly offset from the cotyle by a steep slope. The coracoid shaft is a bit narrower than the cotylar area.

The caudal part of the acrocoracohumeralis ligament scar is preserved, but much of the acrocoracoid is missing. The acrocoracoid projects medially, but does not extend as far medially as the apex of the procoracoid prominence (with the missing tip of the procoracoid process). While much of the furcular facet is missing, the dorsal tip of the facet is preserved indicating that the bone likely did not extend significantly more medially. The caudal margin of the acrocoracoid is approximately level with the cranial tip of the humeral articular facet. The acrocoracoid crest is short and oriented obliquely to the mediolateral axis much like the scapular cotyle.

In dorsal view, the procoracoid prominence extends medially about as far as the humeral articular surface projects laterally. There is no evidence of a procoracoid foramen or notch for the passage of the $n$. supracoracoidei on the preserved coracoid shaft. The preserved ventral margin of the bone is straight suggesting that the acrocoracoid did not extend (far) ventrally. The cranial apex of the acrocoracoid would have been in the ventral half of the process, based on its preserved base. In cranial view, the preserved acrocoracoid has a roughly rectangular outline (though it is crushed a bit).

Remarks

The asymmetric outline of the humeral articular surface with a wider cranial end, a craniocaudally short $\mathrm{m}$. supracoracoideus fossa, and a highly reduced procoracoid process (lacking a $\mathrm{n}$. supracoracoidei foramen) are all features of the pangalliform clade. The presence of a deeply concave scapular cotyle is a crown avian plesiomorphy and indicates a non-crown group phylogenetic status of the specimen since that feature is absent in all crown members of Galliformes (e.g., [14]). The position of the small procoracoid process adjacent to the medial apex of the concave scapular cotyle is consistent with that seen in the extinct Paraortygidae, and differs somewhat from Galliformes, where the likely homologous 
apex of the (reduced) procoracoid prominence appears overall to be a bit more cranially positioned [21]. The long axis of the concave scapular cotyle being offset from a mediolateral (or omal-sternal) orientation with the medial apex positioned omally relative to the sternally positioned lateral apex also is present in, and apparently diagnostic of Paraortygidae $[10,16,21]$. The cotyle is a bit more rounded with a different orientation in the Quercymegapodiidae and other stem taxa $[6,10,16]$. The presence of a short procoracoid process in the fossil is another diagnostic feature of Paraortygidae [16].

The fossil also exhibits a potentially autapomorphic (likely pneumatic) roughly triangular fossa with foramina cranial to the concave scapular cotyle (between the dorsal edges of the $\mathrm{m}$. supracoracoideus fossa and the humeral articular facet) that is not known in any non-crown pangalliform (or galliform) - except for a shallow triangular fossa (lacking foramina) in a specimen of Paraortyx lorteti and a foramen (not within a fossa) in the most recent referred coracoid of Scopelortyx [10,49]. A likely derived feature is the large relative size of the procoracoid prominence (occupying a larger proportion of the $\mathrm{m}$. supracoracoideus fossa) that appears relatively larger than the state in other fossils (such as Gallinuloides) except for Scopelortyx and Xorazmortyx (see Figure 2 in [10]). The new fossil is much smaller than the material referred to the other known North American stem galliforms Gallinuloides, and Palaeonossax and its possible synonyms, but is similar in size to the much younger Nanortyx (with its circular rather than elliptical scapular cotyle), and the similarly-aged Scopelortyx and Xorazmortyx $[2,5,20]$.

No other known stem (or crown) galliform has the (possibly pneumatic) fossa with foramina on the dorsal side of the coracoid just cranial to the scapular cotyle. However, the presence of a single foramen in that position in the coracoid recently referred to Scopelortyx [49], and a specimen of Paraortyx lorteti illustrated by Zelenkov and Panteleyev [10] having a shallow fossa there could suggest that this possibly pneumatic feature is indicative of a pneumatic morphology occurring in paraortygids more broadly. Additional specimens are needed to assess the character's variability and taxonomic utility. In addition, the apex of the enlarged procoracoid prominence (i.e. the procoracoid process) is positioned near the medial apex of the elongate scapular cotyle as in some basal pangalliforms such as Paraortygidae (Scopelortyx from Namibia [16], and Xorazmortyx from Uzbekistan [10]) but the sizes of that prominence and process are larger than in other stem galliforms. In crown galliforms, it appears that the apex of the procoracoid prominence is positioned a bit more towards the omal end of the bone relative to the lateral apex of the flattened scapular cotyle (and the sternal end of the humeral articular facet). The Utah fossil is smaller than the same element in Gallinuloides, Parortygoides (Gallinuloididae), and Procrax (possibly a stem galliform), and the fossil appears to be within the size variation known among members of the non-crown Quercymegapodiidae, Paraortygidae, and Nanortyx $[6,9,10,15,21]$.

Crown group galliforms lack several of the features present in the fossil including the concave scapular cotyle, procoracoid process, enlarged procoracoid prominence, and fossa cranial to the scapular cotyle. Megapodes (Megapodiidae) are the extant sister clade of all other crown galliforms, serving as a basis for (plesiomorphic) comparison among crown clade members. Megapodiids lack the large bulbous procoracoid prominence present in the fossil $[2,14]$. The relative craniocaudal length of the $\mathrm{m}$. supracoracoideus fossa varies within Megapodiidae. The caudal edge of the acrocoracoid is distinctly cranial to the cranial edge of the humeral articular facet in Megapodius laperouse (MVZ 95073) and Aepypodius afrakanius (MVZ 149060), but Megapodius freycinet (MVZ 90031) and Alectura lathami (MVZ 137590) have a relatively craniocaudally shorter fossa. The morphology of the $\mathrm{m}$. supracoracoideus fossa in Alectura lathami differs from the fossil in that it is directed a bit dorsally rather than just medially. The area cranial to the scapular cotyle where the shallow fossa is in the fossil is a broad convex area in the megapodiid skeletons examined. The $\mathrm{m}$. supracoracoideus fossa has pneumatic foramina in Megapodius laperouse and M. freycinet, but there is no evidence of pneumatization of the fossa in Aepypodius afrakanius and Alectura lathami. All specimens of megapodiids examined also are distinctly larger than the Uinta fossil specimen.

The Uintan paraortygid most closely resembles in morphology and size the material placed in Scopelortyx and Xorazmortyx. The sizes of the coracoids of all three species are very similar with the omal 
ends of the coracoids being well under one centimeter in length $[10,16,49]$. They share the enlarged procoracoid prominence, approximate sizes of the procoracoid process, short, oblique acrocoracoid crests, and other aspects of their morphology, but they differ in several features (see diagnostic features above) that distinguish each as a different taxon. The addition of their similar ages ( $\sim 38-44 \mathrm{Ma})$ to that morphological and size similarity could suggest a relatively close phylogenetic affinity among those three species within Paraortygidae.

\section{Discussion}

The Uintan paraortygid specimen has a smooth bone surface consistent with the coracoid deriving from an individual of adult size and morphology. Thus, this coracoid likely is from a relatively small sized individual on par with the smallest extant galliforms and similar in size to some stem galliforms (see above). The length of the omal end of the coracoid (scapular cotyle to cranial tip of the acrocoracoid, and related humeral articular facet length) are approximately the same in the Common Quail Coturnix (MVZ 41337) and the fossil. However, the fossil is stouter (mediolaterally wider) than that of Coturnix and the Taiwan Partridge Arborophila crudigularis (MVZ 50531; which has a relatively longer omal end). The average body mass of those crown galliform taxa, Coturnix ( 90-100 grams) and Arborophila crudigularis ( 200-300 grams), provide an initial estimate of the mass for this stem group species, with the individual the fossil derived from likely being in the 100 to 200 gram range [21].

The smallest extant galliforms are derived odontophorids and phasianids (like Coturnix and Arborphila above), and their small size along with their derived phylogenetic position is likely the result of body mass reduction in those groups rather than plesiomorphy for the crown clade. However, the small size of this fossil along with other smaller non-crown group specimens (e.g., [6,8,10,16,21,49]) is suggestive of a plesiomorphically smaller size in the basal part of the pangalliform clade with a potential body size increase (or series of increases) near the crown node with Sylviornis [11], extant megapodiids, and extant cracids as larger pangalliforms. This hypothesis potentially is supported by the somewhat older ages of the Uintan paraortygid, Scopelortyx, and Xorazmortyx ( 38-44 Ma) relative to the larger late Eocene taxa.

If the Uintan paraortygid, Scopelortyx, and Xorazmortyx form a clade within, or paraphyletic assemblage at the base of Paraortygidae (given their geological ages), then that grouping suggests a relatively rapid and wide ranging intercontinental dispersal distributed across Namibia (Southern Africa, Southern Hemisphere), Uzbekistan (Central Asia, Eastern Hemisphere), and the United States (Western North America, Western Hemisphere). No mammalian taxon has that wide of a geographic distribution in the middle Eocene. Zelenkov and Panteleyev [10] hypothesize that the morphology of Xorazmortyx and Scopelortyx (and paraortygids generally) may have allowed them to be better fliers, and thus better dispersers than other clades of pangalliforms. Without a phylogenetic hypothesis of paraortygid taxa, it is difficult to discuss the potential pattern of intercontinental dispersal that occurred. However, the slightly older age of the Uintan paraortygid relative to Scopelortyx and Xorazmortyx could suggest a pattern of rapid dispersal from North America to Asia to Africa. In addition, the presence of paraortygids in the Eocene of Europe could have occurred during known tetrapod dispersal events between Europe and North America, or through a less likely route (based on known mammalian dispersal patterns) from Asia to Europe.

Townsend et al. [27] support a paleoenvironmental reconstruction of humid forest and woodland habitats during Uinta B times of the Uinta Formation, with a transition to more open and less wooded habitats in stratigraphically higher localities around the receding Lake Uinta. The small size of the fossil coracoid (and hence a small individual) likely relates to an ecological role on the floor of its forest/woodland habitat similar to extant galliforms of similar body size. Mayr [50] and Mayr and Smith [21] suggested that the large crop and ingestion of dietary grit associated with the gizzard (and its increased herbivorous dietary range including dry seeds) evolved along the stem lineage leading to Galliformes, with a large crop apparently absent in Paraortygidae and Gallinuloididae. The evolution of those anatomical features and the shift in dietary breadth might have occurred during the middle 
Eocene gap in the pangalliform record prior to the oldest fossils of Quercymegapodidae, making this interval of time of great interest to future evolutionary biology research. Mayr [50] hypothesized that the shift in anatomy and diet to coarser material might be related to competition with mammalian herbivores and opening up of forest habitats in the Oligocene and Miocene, but with this record of Paraortygidae, the stem lineage leading to Quercymegapodidae and crown Galliformes (with their crops) also shifts earlier in time to $\sim 44 \mathrm{Ma}$, not younger. In addition, the potential occurrence of a quercymegapodiid near the Paleocene-Eocene Boundary in Mongolia [9] would shift that evolutionary event even older, possibly into the Paleocene. These older ages would support evolution of the enlarged crop and gizzard before the opening of terrestrial habitats, and perhaps its evolution was triggered by a new plant resource earlier in the Eocene (or Paleocene). Furthermore, the smaller size of this Uintan pangalliform as compared to Gallinuloides and Procrax likely points to a difference in dietary items consumed and an overall wider ecological role of stem galliforms in North America.

The fossils attributed to Scopelortyx, while recovered from tufa limestone from a spring, have been interpreted as occurring in a semi-arid or arid steppe habitat [16]. The holotype of Xorazmortyx was found in near shore marine sediments with sharks and other fish [10]. Pangalliforms are not aquatic, and clearly the ocean was not that individual's primary habitat. With the Uintan paraortygid deriving from an interior forested habitat (in a wider lake basin), it would seem that the paleoecology of these small-bodied paraortygid birds included occupying a diversity of habitats (coastal, humid forest, and arid steppe). Their small body size and likely lack of a large crop and gizzard in these different settings suggests that their biology was flexible with a diet that was either broad, or focused on a similarly widely-available and abundant food resource.

Today, the galliform fauna of North America comprises some species of Cracidae, members of the New World quail clade Odontophoridae, and members of two clades of related phasianids, turkeys (Meleagridinae) and grouse (Tetraoninae). Mayr [2] states that the published records of late Eocene and early Oligocene records of putative odontophorids need to be verified. Those fossils include Nanorty $x$ and another specimen referred to Odonotphoridae from Colorado $[15,18]$. Their small size is roughly equivalent to extant odontophorids (except that Nanortyx was described as being smaller than living species) as well as the Utah specimen. It is possible that the previously published specimens lie outside the crown clade, and their small size could indicate phylogenetic affinity or possibly similarity in ecology to the Uintan paraortygid. These small fossils might be additional records of paraortygids from North America, as hinted at for the larger Palaeonossax, Procrax, and Archaealectrornis [2]. No Paleogene records of Cracidae are known [20]. The oldest published records of the other galliform clades in North America are from the Neogene [2]. The oldest global records of crown Galliformes are from the Oligocene, but the problematic holotype of Telecrex grangeri is middle Eocene in age (see above) [2]. We know that representatives of stem lineages and the crown clade co-occurred (and potentially competed) in places like Europe (e.g., $[2,6,7])$, but the pattern and timing of galliform faunal change from stem galliform dominated to exclusively galliform composition in North America is unknown. Certainly, both the New World Cracidae and Odontophoridae had to have been present during the Oligocene, but currently we have no definitive records of either group before the Neogene. With the likely origin of the crown group of Phasianidae in Asia, the timing of dispersal of Tetraoninae and Melagridinae into North America is not well constrained beyond their supposed oldest records in the Miocene [51,52]. However, a reexamination of published fossils (in a phylogenetic context) and the discovery of new specimens, such as the fossil from Utah, are needed to better understand the establishment of the modern North American galliform fauna.

Author Contributions: Conceptualization, investigation, writing, and figure production, T.A.S., K.E.B.T., and P.A.H. All authors have read and agreed to the published version of the manuscript.

Funding: This research was funded by the National Natural Sciences Foundation of China (NSFC41772013 to T.A.S.), the Franklin Grant of the American Philosophical Society (to K.E.B.T.), and Midwestern University.

Acknowledgments: Fieldwork was conducted under permit Bureau of Land Management (BLM) Paleontological Resources Use Permit UT-06-031S granted to KET. Figure 2 was adapted from work by P. Higgins, University of 
Rochester. C. Cicero and R. Bowie provided access to modern skeletons in the MVZ. We thank J. Krishna and C. Levitt-Bussian at the Natural History Museum of Utah (UMNH) for facilitating curation. We value comments on a previous version of the manuscript from the anonymous reviewers.

Conflicts of Interest: The authors declare no conflict of interest.

\section{References}

1. Clarke, J. Morphology, phylogenetic taxonomy, and systematics of Ichthyornis and Apatornis (Avialae, Ornithurae). Bull. Am. Mus. Nat. Hist. 2004, 286, 1-179. [CrossRef]

2. Mayr, G. Avian Evolution: The Fossil Record of Birds and Its Paleobiological Significance; Wiley Blackwell: Chichester, UK, 2017; p. 312.

3. Alvarenga, H.M.F. Un primitivo membro da ordem Galliformes (Aves) do Terciário médio da bacia de Taubaté, estado de São Paulo, Brasil. An. Acad. Brasil. Cien. 1995, 67, 33-44.

4. Hwang, S.H.; Mayr, G.; Bolortsetseg, M. The earliest record of a galliform bird in Asia, from the Late Paleocene-Early Eocene of the Gobi Desert, Mongolia. J. Vert. Paleontol. 2010, 30, 1642-1644. [CrossRef]

5. Mayr, G.; Weidig, I. The Early Eocene bird Gallinuloides wyomingensis-A stem group representative of Galliformes. Acta Palaeontol. Pol. 2004, 49, 211-217.

6. Mourer-Chauviré, C. The Galliformes (Aves) from the Phosphorites du Quercy (France): Systematics and biostratigraphy. In Papers in Avian Paleontology Honoring Pierce Brodkorb; Campbell, K.E., Ed.; Science Series; Natural History Museum of Los Angeles County: Los Angeles, CA, USA, 1992; Volume 36, pp. 67-95.

7. Mourer-Chauviré, C. A new species of Ameripodius (Aves: Galliformes: Quercymegapodiidae) from the lower Miocene of France. Palaeontology 2000, 43, 481-493. [CrossRef]

8. Mourer-Chauviré, C.; Tabuce, R.; Essid, E.M.; Marivaux, L.; Khayati, H.; Vianey-Liaud, M.; Ali, M.B.H.; Ali, M.B.H. A new taxon of stem group Galliformes and the earliest record for stem group Cuculidae from the Eocene of Djebel Chambi, Tunisia. In Paleornithological Research 2013, Proceedings of the 8th International Meeting Society of Avian Paleontology and Evolution, Vienna, Austria, 11-16 June 2012; Göhlich, U.B., Kroh, A., Eds.; Natural History Museum of Vienna: Vienna, Austria, 2013; pp. 1-15.

9. Hood, S.C.; Torres, C.R.; Norell, M.; Clark, J.A. New fossil birds from the earliest Eocene of Mongolia. Am. Mus. Nov. 2019, 3934,1-24. [CrossRef]

10. Zelenkov, N.V.; Panteleyev, A.V. A small stem-galliform bird (Aves: Paraortygidae) from the Eocene of Uzbekistan. C. R. Paleovol. 2019, 18, 517-523. [CrossRef]

11. Worthy, T.H.; Mitri, M.; Handley, W.D.; Lee, M.S.Y.; Anderson, A.; Sand, C. Osteology supports a stem-galliform affinity for the giant extinct flightless bird Sylviornis neocaledoniae (Sylviornithidae, Galloanseres). PLoS ONE 2016, 11, e0150871. [CrossRef]

12. Elzanowski, A.; Stidham, T.A. A galloanserine quadrate from the Late Cretaceous Lance Formation of Wyoming. Auk 2011, 128, 138-145. [CrossRef]

13. Hope, S. The Mesozoic radiation of Neornithes. In Mesozoic Birds: Above the Heads of Dinosaurs; Chiappe, L.M., Witmer, L.M., Eds.; University of California Press: Berkeley, CA, USA, 2002; pp. 339-388.

14. Ksepka, D.T. Broken gears in the avian molecular clock: New phylogenetic analyses support stem galliforms status of Gallinuloides wyomingensis and rallid affinities of Amitabha urbsinterditensis. Cladistics 2009, 25, 173-197. [CrossRef]

15. Weigel, R.D. Oligocene birds from Saskatchewan. Quart. J. FLA Sci. 1963, 26, 257-262.

16. Mourer-Chauviré, C.; Pickford, M.; Senut, B. Stem group galliforms and stem group psittaciform birds (Aves, Paraortygidae, and Psittaciformes, incertae sedis) from the Middle Eocene of Namibia. J. Ornith. 2015, 156, 275-286. [CrossRef]

17. Wetmore, A. A fossil guan from the Oligocene of South Dakota. Condor 1956, 58, 234-235.

18. Tordoff, H.B.; MacDonald, J.R. A new bird (Family Cracidae) from the early Oligocene of South Dakota. Auk 1957, 74, 174-184. [CrossRef]

19. Crowe, T.M.; Short, L.L. A new gallinaceous bird from the Oligocene of Nebraska, with comments on the phylogenetic position of the Gallinuloididae. In Papers in Avian Paleontology Honoring Pierce Brodkorb; Campbell, K.E., Ed.; Science Series; Natural History Museum of Los Angeles County: Los Angeles, CA, USA, 1992; Volume 36, pp. 179-185.

20. Mayr, G. Paleogene Fossil Birds; Springer: Berlin, Germany, 2009; p. 262. 
21. Dunning, J.B., Jr. CRC Handbook of Avian Body Masses, 2nd ed.; CRC Press: Boca Raton, FL, USA, 2008 ; p. 655.

22. Mayr, G.; Smith, T. Galliformes, Upupiformes, Trogoniformes, and other avian remains (Phaethontiformes and Threskiornithidae) from the Rupelian stratotype in Belgium, with comments on the identity of "Anas" benedeni Sharpe, 1899. In Paleornithological Research 2013, Proceedings of the 8th International Meeting Society of Avian Paleontology and Evolution, Vienna, Austria, 11-16 June 2012; Göhlich, U.B., Kroh, A., Eds.; Natural History Museum of Vienna: Vienna, Austria, 2013; pp. 23-35.

23. Mourer-Chauviré, C.; Pickford, M.; Senut, B. The first Palaeogene galliform from Africa. J. Ornith. 2011, 152, 617-622.

24. Olson, S.L. Telecrex restudied: A small Eocene guineafowl. Wilson Bull. 1974, 86, $246-250$.

25. Fostowicz-Frelik, Ł.; Li, C.; Mao, F.; Meng, J.; Wang, Y. A large mimotonid from the Middle Eocene of China sheds light on the evolution of lagomorphs and their kin. Sci. Rep. 2015, 5, 1-9. [CrossRef]

26. Townsend, K.E.B.; Friscia, A.R.; Rasmussen, D.T. Stratigraphic distribution of upper middle Eocene fossil vertebrate localities in the eastern Uinta Basin, Utah, with comments on Uintan biostratigraphy. Mtn. Geol. 2006, 43, 115-134.

27. Townsend, K.; Rasmussen, D.T.; Murphey, P.C.; Evanoff, E. Middle Eocene habitat shifts in the North American western interior: A case study. Palaeogeo. Palaeoclim. Palaeoeco. 2010, 297, 144-158. [CrossRef]

28. Prothero, D.R. Magnetic stratigraphy and biostratigraphy of the middle Eocene Uinta Formation, Uinta Basin, Utah. In The Terrestrial Eocene-Oligocene Transition in North America; Prothero, D.R., Emry, R.J., Eds.; Cambridge University Press: Cambridge, UK, 1996; pp. 75-119.

29. Peterson, O.A.; Kay, J.L. The upper Uinta Formation of northeastern Utah. Ann. Carn. Mus. 1931, 20, $293-306$.

30. Bryant, B.; Naeser, C.W.; Marvin, R.F.; Mehnert, H.H. Upper Cretaceous and Paleogene sedimentary rocks and isotopic ages of Paleogene tuffs, Uinta Basin, Utah. U.S. Geol. Surv. Bull. 1989, 1787, 1-22.

31. Hamblin, A.H.; Sarjeant, W.A.S.; Spalding, D.A.E. Vertebrate footprints in the Duchesne River and Uinta Formations (middle to late Eocene), Uinta Basin, Utah. In Vertebrate Paleontology in Utah; Gillette, D.D., Ed.; Utah Geological Survey Miscellaneous Publication: Salt Lake City, UT, USA, 1999; Volume 99, pp. $443-454$.

32. Interim Geologic Map of the Vernal 30' $\times 60^{\prime}$ Quadrangle. Available online: https://ugspub.nr.utah.gov/ publications/open_file_reports/ofr-506.pdf (accessed on 1 January 2007).

33. Interim Geologic Map of the Seep Ridge 30' $\times 60^{\prime}$ Quadrangle. Available online: http://www.mapstore.utah. gov/ofr549.html (accessed on 1 January 2009).

34. Interim Geologic Map of the East Part of the Duchesne 30' $\times 60^{\prime}$ Quadrangle. Available online: http: //ugspub.nr.utah.gov/publications/open_file_reports/ofr-647.pdf (accessed on 3 November 2015).

35. Murphey, P.C.; Townsend KE, B.; Friscia, A.R.; Westgate, J.; Evanoff, E.; Gunnell, G.F. Paleontology and stratigraphy of middle Eocene rock units in the southern Green River and Uinta Basins, Wyoming and Utah. Geol. Inter. West 2017, 4, 1-53. [CrossRef]

36. Ryder, R.T.; Fouch, T.D.; Elison, J.H. Early Tertiary sedimentation in the western Uinta Basin, Utah. Geol. Soc. Am. Bull. 1976, 87, 496-512. [CrossRef]

37. Osborn, H.F. The Titanotheres of Ancient Wyoming, Dakota, and Nebraska; Department of the Interior, United States Geological Survey: Liston, VA, USA, 1929; Volume 55, p. 953.

38. Wood, H.E.; Chaney, R.W.; Clark, J.; Colbert, E.H.; Jepsen, G.L.; Reeside, J.B.; Stock, C. Nomenclature and correlation of the North American continental Tertiary. Geol. Soc. Am. Bull. 1941, 52, 1-48. [CrossRef]

39. Geological Map of the Southam Canyon Quadrangle, Uintah County, Utah. U.S. Available online: https: //pubs.er.usgs.gov/publication/mf579 (accessed on 3 November 2015).

40. Geological Map of the Bonanza Quadrangle, Uintah County, Utah. U.S. Available online: https://pubs.er. usgs.gov/publication/mf1865 (accessed on 15 January 2020).

41. Riggs, E.S. New or little known Titanotheres from the lower Uintah formations. Field Mus. Nat. Hist. Geol. Ser. 1912, 159, 17-41.

42. Gunnell, G.F.; Murphey, P.C.; Stucky, R.K.; Townsend, K.B.; Robinson, P.; Zonneveld, J.; Bartels, W.; Albright III, L. Biostratigraphy and biochronology of the latest Wasatchian, Bridgerian, and Uintan North American land mammal "ages". In Papers on Geology, Vertebrate Paleontology, and Biostratigraphy in Honor of Michael O. Woodburne; Albright, L., III, Ed.; Museum of Northern Arizona Bulletin: Flagstaff, AZ, USA, 2009; Volume 65, pp. 279-330.

43. Wetmore, A. A fossil duck from the Eocene of Utah. J. Paleo. 1938, 12, 280-283. 
44. Olson, S.L.; Feduccia, A. Presbyornis and the origin of the Anseriformes (Aves: Charadriomorphae). Smith. Cont. Zool. 1980, 323, 1-24. [CrossRef]

45. Cracraft, J. Systematics and Evolution of the Gruiformes (Class Aves) 2. Additional comments on the Bathornithidae, with descriptions of new species. Am. Mus. Novit. 1971, 2449, 1-13.

46. Mayr, G. Osteology and phylogenetic affinities of the middle Eocene North American Bathornis grallator-One of the best represented, albeit least known Paleogene cariamiform birds (seriemas and allies). J. Paleont. 2016, 90, 357-374. [CrossRef]

47. Baumel, J.J.; Witmer, L. Osteologica. In Handbook of Avian Anatomy: Nomina Anatomica Avium, 2nd ed.; Baumel, J.J., King, A.S., Breazile, J.E., Evans, H.E., Vanden Berge, J.C., Eds.; Publications of the Nuttall Ornithological Club: Cambridge, MA, USA, 1993; Volume 23, pp. 45-132.

48. Mourer-Chauviré, C.; Pickford, M.; Senut, B. New data on stem group Galliformes, Charadriiformes, and Psittaciformes from the middle Eocene of Namibia. In Paleontologia y Evolucion de las Aves; Acosta Hospitaleche, C., Agnolin, F., Haidr, N., Noriega, J.I., Tambussi, C., Eds.; Museo Argentino de Ciencias Naturales “Bernardino Rivadavia”: Buenos-Aires, Argentina, 2017; pp. 99-131.

49. Linnaeus, C. Systema Naturae per Regna Tria Naturae, Secundum Classes, Ordines, Genera, Species, Cum Characteribus, Differentiis, Synonymis, Locis; Tomus I. Editio Decima, Reformata; Impensis Direct. Laurentii Salvii: Holmiae, Sweden, 1758.

50. Mayr, G. New specimens of the early Eocene stem group galliforms Parortygoides (Gallinuloididae), with comments on the evolution of a crop in the stem lineage of Galliformes. J. Ornithol. 2006, 147, 31-37. [CrossRef]

51. Miller, A. An avifauna from the lower Miocene of South Dakota. Univ. Cal. Pub. Bull. Dept. Geol. Sci. 1944, 27, 85-100.

52. Olson, S.L.; Farrand, J. Rhegminornis restudied: A tiny Miocene turkey. Wilson Bull. 1974, 86, 114-120.

(C) 2020 by the authors. Licensee MDPI, Basel, Switzerland. This article is an open access article distributed under the terms and conditions of the Creative Commons Attribution (CC BY) license (http://creativecommons.org/licenses/by/4.0/). 